\title{
Economic cooperation and Peaceful Settlement of the Arab-Israeli Conflict: Middle-Easternism and the Amman Economic Summit as a Model
}

\author{
Dr. Mohammad Youssef Daradkeh \\ Assistance Professor \\ Al-Bayet University-The wisdom Institute
}

\begin{abstract}
This study comprises of three chapters: The economy in international relations, Middle East peace and economy, and the Middle East through the reality of economic conferences in Morocco and Amman for the years 1994-1995. The choice of the major search problem is represented by the extent of correlation of the economic and political paths for the success of Middle-Easternism. The results showed the weakness of the interdependence between different the two paths and revealed a contrast between the objectives of all parties in the Middle East on three major levels of descriptive analysis: The Israeli, the Arabic and the international.
\end{abstract}

Keywords: Peace, Peaceful Settlement, Middle East, Globalization, International Economy.

\section{Middle-Easternism and the Amman Economic Summit}

\subsection{Introduction}

The significance of this study stems from the transformations that took place on the international scene with regards to the Middle East after the end of the Second Gulf War and beginning of the peace process in the Madrid Conference to solve the Arab-Israeli conflict in order to established a regional system-- with all its mechanisms, principles, theoretical and practical premises, that would bring the Arabs and the Israelis together. This lead to the emergence of idea of the Middle-Easternism as a new regional system. And as the international economy started to take the shape of large economic blocs, there emerged a need to promote the economic factor as a pathway towards formulating the idea of Middle-Easternism and the rise of a regional system to achieve the primary goal of Middle-Easternism. But the major questions that arise in this context are as follows:

Will there be a correlation between the economic and the political tracks of the idea of Middle-Easternism? And what is the position of the involved parties with regards to this case? What is the impact of the prevalence of one track over the other on this entire process - such as if the political track falters, for example? Does this idea seek to create a new regional system as an alternative to the Arab regional order and Arab cooperation? These questions are what the search will attempt to answer through three chapters. The first chapter addresses the role of Economics in the dynamics of international relations in terms of its features and characteristics, and the general trends in the movement of the international economy in general. The second chapter will discuss the Middle-Eastern vision with its economic track by examining the concept of the Middle East and its origin, and then discuss the international economy, MiddleEasternism and the sources of funding for the project. And finally, the issues facing the Middle East at three levels: International, Arab and Israeli.

The third and last chapter with attempt to address the Casablanca Economic Summit of 1994, and the Amman Conference of 1995 in terms of their dimensions, goals and results, then compare between their summits in order to reach a set of conclusions at the end of the study.

\subsection{Research significance:}

1. Scientific importance: The significance of this study appears by knowing the relationship between economy peace and political resolution of the Arab-Israeli conflict through the idea of Middle-Easternism some applications of which appeared in the summits of Casablanca in 1994 and Amman in 1995.

2. Practical significance: Rationalization of decision-making in Arab political systems and Arab political and civil society forces by analyzing the idea of middle-Easternism as a way towards peaceful settlement.

\subsection{Research objectives:}

1. Knowledge of the pillars of the idea of Middle-Easternism.

2. Knowledge of the political and economic aspects of the idea of Middle-Easternism.

3. Analyzing the contents of the summits of Morocco and Amman for the years 1994-1995 to know the two previous goals. 


\subsection{Concepts used:}

1. Peace: a condition reached by the negotiating parties in accordance with the principles of justice and equity.

2. Peaceful settlement: The process through which the negotiating parties reach solutions accordance of power balance.

\subsection{Research problem:}

1. The main problem appears in the central question: Is there a correlation between the economic track and the political course of the Middle East idea? The researcher answered the previous question through a series of sub-questions:

2. What is the position of the parties involved in the Middle East process?

3. Is the Middle East aimed at creating a new regional system instead of the Arab regional system?

\section{6: Study hypotheses:}

This research is based on a set of hypotheses, the most important of which are:

1. As the economic interdependence between the countries of the Arab-Israeli conflict increases, it may lead to a peaceful settlement of the conflict.

2. The greater the disparity in the pace of the peace process and slower the movement of the Middle East process.

3. The greater the international pressure to support the economic projects of the countries of conflict, the greater the chance of success of the Middle East process.

\subsection{The approach used:}

The uses the descriptive analytical approach to study the parties participating and sponsoring the idea of MiddleEasternism at the Arab, Israeli and International levels while at the same time using the content analysis approach to compare the two summits of Morocco 1994 and Amman 1995, in terms of their results to find out the main practical obstacles that impede the success of the idea of Middle-Easternism.

\section{The Economy in International Relations:}

The issue of mutual interests appears most clearly in the field of economics and trade. This is because the common economic interest creates economic bodies which are closely interrelated which in turn poses pressure on states that engage in economic exchange in the case they were violated. This in turn causes a sense of order in international relations. The assumption supports the internationalism spirit which means that mutual interests between states are stronger, greater and more important than the disagreements the may occur between them. ${ }^{1}$

The globalization of the international economy "is another development that is likely to make significant changes in the structure and processes of the international system in the years to come in controlling conflicts and reducing the likelihood of war. Economic interdependence between countries' economies reduces the adventure of war and conflict. For example, The United States has not exercised its coercion against Japan for fear of increased diplomatic tensions much, leading to the expulsion of thousands of Japanese investors in the United States, which leads to the cessation or decline of economic growth, which increases the unemployment rates in America ", the link and intertwining between the economies Japan And the United States to restrain and restrain policy interactions so that the economic factor is active in policy interactions and therefore more effective in international relations, as emphasized by John Major, Britain's prime minister, where international trade, globalization of the economy create peace, then when the sales of General Motors Co. surpass the national products of Indonesia, Turkey and Yugoslavia, in addition to the fact the annual growth of multi-national companies are two or three times the size of the growth of states in the United Nations. ${ }^{2345}$

Furthermore, international policies tend to take up non-political features. If we look the Canadian-American relations, we may observe the impact of the economic factor in building mutual interests and taking part the NAFTA agreement where trade was the primary binding element in this relationship, "trade can play the role of a political connection between states when it broadens the mutual interests of these states. For example: the traditional friendship between the US and Canada is fortified by the trade cooperation between them.

\footnotetext{
${ }^{1}$ Nafeh's Political Encyclopedia. (1969). Vol.1. P.655.

${ }^{2}$ Holsti, K.J. 7. (1995). International Politics: A Frame Work for Analysis. Prentice Hall Inc. 7th edition.

${ }^{3}$ Ibid, P. 77.

${ }^{4}$ Ibid, P. 78.

${ }^{5}$ Theodore; Coulombis; Wolfe, James. (1982). Introduction to International Relations: Power and Justice. Prentice-Hall inc Engle Wood Cliffs. 2nd Edition. P. 356.
} 
Canada, for instance, is the US's biggest export market, which in turn creates a unity of interests which encourages the solution of political issues which may hinder the mutual beneficial relation between the two states. Therefore, the mutual economic inter-dependence is in growing increase since widening international trade is indeed a necessary for economic growth, and an integral part of the economic dimension of development and the benefits of increasing trade and commercial exchange, as it leads to decreasing the expenses of trade transactions, increasing economic opportunities and strengthening trust and security at the international level. ${ }^{67}$ From this, it becomes clear that the economic factor increases the mutual interests and widening their scope, therefore decreasing economic clashes and conflicts to preserve economic interests, which establishes a state of order in international relations based on organized competition as opposed to uncontrollable chaos and conflict. Thus, the economic dimension is gets gradually closer to the top of the agenda of international politics on the basis that the internal community became interconnected.

Since the economic world has a increasing role in the movement of international relations. Where history was merely a series of political and military conflicts in the not so distant past, today, on the other hand, international relations are based on economy and it became the predominant theme. The economic competition towards the markets nowadays fortifies and supports the state's national security as its share in these markets increases. But a state on its own cannot achieve all of its interests on the international arena. For that reason, there emerged a need to form and establish economic blocs which foster the mutual interests of the parties participating in these blocs. In addition, the states' grip on the economic process inside and out decreases at the expense of the private sector and multi-national corporations which caused the emergence of concept of the privatization of international economy. From all this, we can say that the economic factor began to take up a significant role. But where does the Third World stand in all of this? ${ }^{8}$

Since in today's world there is no state living in a complete economic isolation, then the real process of specialization and trade leads of a massive set of mutual trade-offs. But the international economic relations have moved to a new formation after being based on the Bretton Woods system since its political foundations were based on three rules: the concentration of power in a limited number of states, the presence of significant mutual interests between these states and the will to possess power. These, in turn, established what is know as the leadership role. ${ }^{910}$

But this situation has gradually changed until both Europe and Japan no longer accepted America's leading role for security reasons. In addition, the United States no longer wants to shoulder the economic burden imposed on it as a leader to protect international security. Yet Lolan is optimistic that the 1980s will end the fraud. "The United States will not be able to continue to cheat in the energy field, it is pushing more and more the market price of oil and you will find Japan and Western Europe will find themselves force to cease their fraud in the area of security to account for a greater share of the military burden ". ${ }^{11}$ Third World countries can be divided into Third World countries and fourth world countries because the third world countries have a presence in the report of international economic relations while the fourth world countries are going towards marginalization, but the economic unity of the south and their ability to take actions that harm the interests of the countries of the center (Core States), as well as the competition of these rich countries on the markets of the poor countries reduces the possibility of economic marginalization of these countries and more responsive to their demands in order to maintain stability.

We conclude from the aforementioned statement on the role of the economy in international relations that:

1. The economy is taking on an increasing role in international relations, which will increasingly create an international interdependent economic community and strengthen international interdependence.

2. The new economic system adopts multilateral management and that the distribution of power among the countries of the Center in the management of the international economy requires the active participation of many countries.

3. The attempts of the rich countries of the Center to resolve the political conflicts from different areas of political tension, especially the Middle East and the Arab-Israeli conflict, with a political and economic path.

This is the attempt to establish the peace economics of the region within a new Middle East vision to formulate a new regional system that will be discussed in Chapters 2 and 3.

${ }^{6}$ Kantor, Robert; Zaher, Ahmed (translator). (1989). Contemporary International Politics. Amman: Jordan Book Center. p. 163.

${ }^{7}$ Ghali, Boutros. (1994). Development and International Economic Cooperation. International Policy, No. 117. p. 16.

${ }^{8}$ Peres, Shimon; Helmy Abdel Hafez, Mohamed. (1994). The New Middle East. Amman: Al Ahlia Publishing and

Distribution, 1. p. 104.

${ }^{9}$ Harrison, John, et al.; Abdullah Mansour, Taha. (translator) (1987). International Economic Relations. Dar Al-Marikh Publishing. p. 265.

${ }^{10}$ Spero, Jean E. The Politics of International Relations. London: George Allen. P.21.

${ }^{11}$ Hussein Agha, et al. (1982). World Economic Issues. Beirut: Arab Institute for Studies and Publications. 1. p. 188.

152 
4. The participatory management of the international economy presented in the second point is steadily increasing with the increase of European political and economic unity, within a reformist interrelationship between the countries of the Center with a stronger competition that fluctuates in power. It from here that the Mediterranean idea had practically begun in Barcelona conference.

\section{Middle-Easternism and Peace Economy:}

\subsection{The concept of the Middle East and its implications:}

The Middle Eastern idea is based on the Peresian theory of creating a regional family of nations with a common market and selected central bodies, similar to the European Community according to four pillars: political stability, economy, national security and democratization; and thus forming relations at the two levels of nation. According to Shimon Peres, "the Middle East now needs an approach similar to that of Jean Monnet. We need bravery and thought of race, imagination and depth. We need to remove the laurels' certainty, to see that things could not have been better than they are, and nothing new under the sun of time ". ${ }^{12}$

But before talking about the relationship between the international economic track as we have seen in the previous chapter and the Middle East as an idea and an economic project at the beginning, but aims at reaching the end of the political solutions and achieve the goal of international stability in the interest of the rich countries of the Center in order to preserve its range of vital interests, to address the definition of the Middle East and its origin geographically. The concept of "Middle East" was linked to British strategic thinking. During 1902-1903, ValintenSherall wrote a series of articles entitled "The Middle East Question". In London, Hamelton wrote the Middle East problems in 1909. Theis concept was based on the path leading to India and China, and finally included in its 18 axes within its membership and extended its range from Iran in the east to Malta in the west, and from Iraq and Syria in the north until Ethiopia and Eritrea in the south after the Second World War with the British in 1940 established the "East Supply Center," which influenced the implications this concept, so the political significance has shifted to according to the following indicators: ${ }^{13}$

1. This concept does not go to a specific geographical area, it is a political term in its inception and use by external forces.

2. This concept ruptures the Arab world and does not treat it as a distinct unit. It uses non-Arab countries such as Turkey, Iran, Israel, sometimes Pakistan, Afghanistan, Ethiopia and Cyprus, and excludes the countries of Morocco, Algeria, Tunisia and sometimes Libya, and this is perhaps the meaning of the Middle East and North Africa. This concept makes Arab countries part of a mosaic area that includes a mix of nationalities, peoples, races, religions, languages, its base, pluralism and diversity, not unity and symmetry.

3. It aims at justifying the legitimacy of Israel's presence in the Middle East. Sayyar Gemayel, on the other hands, thinks the Middle East region is wider than the Near East and its enjoying its pecifications, configurations, complexity and pleasantness, connecting East and West. It is composed of a diverse group of regions located in south-west Asia, which is the center of the world, and it is considered one of the richest regions in the world with its oil wealth, which is the in middle of the two Easts: the near East and the far. ${ }^{14}$

\subsection{International Economy and Middle-Easternism:}

We have said previously that the international economy will be managed in a participatory manner by the countries of the Center under a framework of orderly competition for foreign markets, which will include the Middle East region, the concept of which we have explained previously. This requires the promotion of political stability of one of the pillars of the Middle East system proposed by Shimon Peres, the former Prime Minister of the State of Israel, and thus the Middle East as a proposed idea is applicable and requires the availability of political conditions in accordance with the requirements of the economic condition, which shows that the relationship between the two conditions is a complementary relationship, as the economy and joint ventures show common interests and, "we can use global funds to set up a fund for the development of the Middle East, allowing each country to use its own resources". ${ }^{15}$

The sources of funding for this project in the Middle East are:

\footnotetext{
${ }^{12}$ Peres, Shimon. Helmy Abdel Hafiz, Mohamed (translator). (1994). The New Middle East. Amman: Dar Al Ahlia Publishing and Distribution, 1.p. 75.

${ }^{13}$ Abdullah Moawad, Jalal. (1994). The Middle East: Implications and Current and Potential Developments. Arab Affairs, 80. p. 41.

${ }^{14}$ Gemayel, Sayyar. (1990). The Vital Field of the Middle East. Beirut: The Arab Future, Center for Arab Unity Studies. p. 6.

${ }^{15}$ Peres, Shimon; Helmy Abdel Hafez, Mohamed (translator). (1994). The New Middle East. Amman: Al Ahlia Publishing and Distribution. p. 100.
} 
1. The contribution of the international private sector to the establishment of economic projects in the region.

2. Income generated from the sale of oil.

3. Reduction of money spent in defense budgets of the countries in the region, and investing in the econ. According to Peres, "these confrontations have forced the various governments concerned to privatize large sums of money and resources for the development of their armies, the construction of their infrastructure and the military, even in times of war, and the Middle East during the 1980s, ranked first among the world's regions in spending on arms and armaments for total national production as the cost of one day of the total cost of the war is not less than $\$ 1$ billion for Israel."16

All this is reflected in one way or another on the peoples of the region in terms of well-being and the growing income gap between the countries of the region itself and the countries of the region and Europe. "There are about 224 million people in the Middle East, with an average per capita income of $\$ 1200$ per year, which ammounts to $10 \%$ of the income in Europe, and the widening gap between oil producing countries and other countries in the region. These are the foundations and the starting points of the theoretical Middle Eastern idea, but the problems of this perception are large and large by all parties. ${ }^{17}$

\subsection{Problems of Middle-Easternism:}

The problems of Middle=Easternism can be divided into three levels: the first level is the Arab level and its position on the project. The second level is at the international level: Europe and America, and the third level is the Israeli level and its position from the Middle East, especially after the Likud took power in Israel.

\subsubsection{The Arab level of Middle-easterism:}

Two levels can be addressed within this level of the Middle East: The level of intellectual elites and the level of political systems. In terms of the first level, intellectual elites stand on three positions:

1. The first is to accept the settlement with Israel as it accepts a Middle Eastern system because of the global changes that must be carried out in its procession and not to fear normalization. Arab culture and civilization are strong, but are seen as a challenge that enables the Arabs to reorganize their positions and coordinate their positions. Especially as it is an imposed challenge that the Arabs must enter in terms of unity and strength, not division and division, so as to ensure that the Middle East framework respects the existing identities of the region, primarily the Arab and Islamic identities, Li based in the region, particularly the Arab League mechanisms ", and therefore this trend that sees no contradiction between the Arab system Bmassth League of Arab States and the Middle East system, but on the Arab countries to take the lead in. ${ }^{18}$

2. The second position is to accept a peaceful settlement and am Eastern Mediterranean system, but it does not accept normalization to preserve the Arabic identity of being lost through dismantling and re-assembling the Arabian region on the basis of non-national geography. ${ }^{19}$

3. The third position: rejects the settlement, normalization and the Middle East order, and considers it an AmericanZionist conspiracy to achieve their interests in the region after the destruction of all psychological, social and intellectual barriers and entering into economic interests with the State of Israel.

The Arab official perception of the Middle East project is divided on itself. Both Saudi Arabia and the Gulf countries rejected the idea of financing the Middle East Development Bank and contributing to it because there are Arab funds to finance joint projects. "The Arab rejection - especially the Saudi - Conviction of the very idea of establishing the bank." ${ }^{20}$ Thus we lack a unified Arab vision among Arabic States on the Middle Eastern and Arab regime and its lack of vision among the intellectual currents of the region in connection with the project, which is ultimately a problem and difficulty.

\subsubsection{The International level of Middle-Easternism:}

Opinions differ on this project between Europe and America, where the latter strongly supports the project. This disagreement is evident in the position of the establishment of the Middle East Development Bank, where the major European powers, particularly Germany, reject the idea of financing the project as an American idea that primarily serves American interests.

\footnotetext{
${ }^{16}$ Peres, Shimon. The New Middle East. op. cit.. pp. 93-97.

${ }^{17}$ Ibid., P. 98.

${ }^{18}$ Journal of politics, 127. (January 1997). p. 194.

${ }^{19}$ Zakaria Ismail, Mohammed. (1995). The Arab Regime and the Middle East System. Beirut: The Arab Future, 196. pp. 1819.

${ }^{20}$ Journal of International Politics, 127. (January, 1997). p. 249.

154
} 
"Casablanca, which plays a minor role in the American plans for the Middle East, and does not receive much attention in the international decisions taken on the region and whether the United States deliberately marginalizes the European role or not. The European states, led by Germany, have quite logically rejected the idea of financing an institution controlled by the US dollar and US leadership.". And this can be explained by the emergence of the Mediterranean idea represented at the Barcelona conference by the major European countries, and here shows another problem at the level of implementation of the Middle East Project of the different European vision. ${ }^{21}$

\subsubsection{The Israeli level of Middle-Easternism:}

The Israeli level became an obstacle to the project after the Likud Party took power in the State of Israel. The party was interested in achieving Israeli security and peace. The project is considered an prelude to impose political concessions on Israel that threatens its security in the future.

"It can be said that Likud's policy implicitly rejects the Middle East principle that the Israeli Labor Party has long advocated, because according to the Likud, Middle-Easternism has weakened the Israeli position in the negotiations in a way that forced it to accept Political conditions in peace negotiations that are unfair to them."22

It is clear then, by looking at the foundations and perspectives of the Middle East and the factors that led to their emergence after the radical changes in international relations after the end of the Cold War and the direction of international relations to the geo-economic interactions and the search for an agreement to achieve political, economic and security stability in the Middle East, that all these pillars and premises do not prevent the existence of problems represented by differences at the Arab, international and Israeli levels towards the Middle East project, which allows us to say that the project seems difficult to achieve and apply, especially if the bilateral political process between the Arab parties and Israel stops or collapses in dealing with the most serious and central conflict in the Middle East, and the failure of the Cairo conference (1996) as a stage of implementation and implementation of the Middle East project.

\section{Middle-Easternsim in the reality of economic conferences:}

In this chapter, we will discuss economic conferences within the framework of the implementation of the economic course of the Middle-Eastern idea: the Casablanca Conference in 1994, the Amman Conference in 1995, and the commonalities of these Middle Eastern conferences:

\subsection{The Casablanca Conference:}

The Casablanca conference was designed to be similar to the Madrid Conference, a new platform that would contribute to creating a path of cooperation and economic normalization between Israel and the Arab nation. This time, it will be the entrance of the private sector and thus contribute to creating a parallel path to the political process. Shimon Peres said that the Casablanca conference is not aimed at political negotiation for peace, nor supporting peace militarily, but for building economic peace through building a Middle East. The US secretary of state also focused on the role of the private sector, which can create lasting peace through sustainable growth and development. The continuation of the Declaration of Casablanca, which was launched in 1956 as the European Union's construction process, was confirmed by André Azoulay, advisor to King Hassan II of Morocco.

The participation in the Casablanca Conference reflects the importance of the implementation of peace on the economic track, with the attendance of about 3,000 personalities among Heads of State or their representatives and some public personalities and security personnel from some 61 participating countries. ${ }^{23}$

This conference resulted in a number of indicators that illustrate its characteristics and general features, and they can be listed as follows:

1. The conference presented the so-called consolidation of the peace process, calling for the convening of two informal organizations: the Council on International Relations in America and the Davos World Forum.

2. The conference showed the size of the Israeli preparation for it and the preparation so that its results came in its favor $^{24}$.

Therefore, if we look at the conference papers and its results, we find that the conference succeeded in favor of Israel at the expense of the interests of the Arab countries. Israel went to Casablanca with 150 investment projects covering all the areas that are strategic and vital to her. ${ }^{25}$

\footnotetext{
${ }^{21}$ Ibid., P. 249.

${ }^{22}$ Journal of International Politics, 127. (January, 1997). p. 250.

${ }^{23}$ Journal of International Politics, 127. (January, 1997). p. 247.

${ }^{24}$ Journal of International Politics, 127. (January, 1997), p. 248.

${ }^{25}$ Ibid., No. 117. (January, 1997). p. 248.
} 
The Casablanca Declaration is the heart of priorities. Instead of comprehensive peace first being followed by normalization and economic projects, the preamble of the Declaration modifies previous priorities, making priority for normalization and economic projects a claim that economic development Balanced is the mainstay of comprehensive peace.

It was decided to establish three institutions: the Development Bank, the Regional Tourism Council, and the third by establishing the Trade and Business Bureau. Thus, Israel helped to achieve its integration into the Middle East region and to gain recognition as one of the countries in the region.

\subsection{Amman Economic Summit:}

\subsection{1: The size of the Amman summit:}

The number of participants reached some 2,000 representatives from 63 countries with the aim of establishing the institutional structure necessary to implement the Casablanca recommendations or outcomes.

\subsubsection{Political circumstances surrounding the convening of the Amman Summit:}

The region witnessed several political circumstances during the convening of the Amman summit, including: The assassination of FathiShikaki, the Secretary-General of the Islamic Jihad Organization. Yitzhak Rabin emphasized that Jerusalem is the eternal capital of the State of Israel. Congress confirmed this principle and decided to move the US Embassy from Tel Aviv to Jerusalem, by the end of 1999, which took place during the Trump era in 2018. And despite the existence of these conditions that hinder the political course of the settlement, the economic path continued nonetheless.

\subsubsection{Amman Summit Highlights:}

1. Considering the Amman Summit as a continuation and implementation of the recommendations of Casablanca.

2. The number of participating countries rose from 61 in Casablanca to 63 in the Amman Summit. The number of Arab countries increased from 12 to 13 with the accession of Mauritania, with the absence of Libya, Sudan, Iraq, Syria and Lebanon. The number of participants also rose to 1400 as opposed to 1114 in Casablanca. ${ }^{26}$

3. The Israeli representation in the Amman summit was severely reduced to 85, following the large attendance in Casablanca which raised concerns about the Israeli goals of participating in the conference. ${ }^{27}$

\subsubsection{Amman Summit results:}

The Amman Summit resulted in a number of outputs, the most important of which are:

1. The establishment of the Middle East Development Bank, which has been the subject of disagreement between major European countries (Germany and France) and Gulf states such as Saudi Arabia and the United Arab Emirates since the Casablanca conference. The United States was pressing in various ways for the Bank's idea to succeed. Jordan did not welcome the idea of the establishment of the bank along the major European countries of Germany and France at the time, and it is still rejected by both Saudi Arabia and the UAE, and this rejection was based on the following data: ${ }^{28}$

- With regard to the European side, it is considered a means of dominance for the American administration on the policies of the bank in such a way that gives it a role in the privatization of certain items and the elimination of others in accordance with their interests and priorities.

- As for the Arab side, the rejection came on the basis that Israel aims to reach the Gulf funds and benefit from them for her interests rather than having sufficient Arab financing institutions, in addition to the fact that the peace process has not been completed on its Syrian, Lebanese and Palestinian tracks.

- The establishment of a regional tourism institution aims to develop tourism exchange between the countries of the region in addition to the promotion of foreign tourism. Israel is also remarkably interested in the field of tourism.

- Enhancing the role played by the private sector in the region. The Regional Business and Trade Council is supposed to involve businessmen and private companies operating in the region.

\subsubsection{The Amman Summit premises:}

The Amman Summit is based on a fundamental premise which is the basis of the economic process of the peaceful settlement process, which proves that the project is for political ends by economic means. These principles are:

\footnotetext{
${ }^{26}$ Journal of the Future Arab. No. 204. (February, 1996) p. 14.

${ }^{27}$ Journal of the Future Arab. No. 204. (February, 1996) p. 14.

${ }^{28}$ Journal of International Politics. No. 126. (October, 1996) p. 153.

156
} 
1. Peace cannot endure without tangible benefits for the peoples of the region, benefits that can only be achieved through increased trade and investment.

2. The need for regional cooperation among the countries of the region, especially in vital areas.

3. The Summit reached five good institutions for economic cooperation ${ }^{29}$ :

4. Bank for Economic Cooperation and Development and the Middle East and North Africa, based in Cairo.

5. Establishment of the Regional Tourism Council for the Middle East and the Mediterranean.

6. Establishment of the Regional Business Council to strengthen cooperation and trade.

7. The official opening of the Executive General Secretariat of the Economic Summit based in Rabat.

8. The establishment of the General Secretariat of the Follow-up Committee of the Regional Working Group on Economic Development, thus bringing the peace process into its institutional framework. But in view of the Casablanca Declaration and the Amman Economic Summit, the final conclusions can be reached by reading the interactions, dynamics and pillars of the Middle East track that it addressed.

\section{Final results:}

1. The weakness of Arab coordination in economic conferences and the trend towards bilateral projects with Israel, such as the gas transfer project with Qatar and the Jordanian-Israeli talks to formulate joint projects.

2. The Israeli preparations were also evident in both the Casablanca and Amman summits rather than Israel's focus on problems that compensated and addressed the problem of the lack of natural resources such as water.

3. The occurrence and direction of customizing the peace process as a basis for the Middle East process and giving a special role for the private sector in joint ventures in the region to ensure creating irreversible common interests in the future.

4. Jordan's tendency to give regional cooperation a priority to advance the economic process of the Middle East process while reconciling Egypt's economic and political track with the Middle East.

5. America's attempt to lead the Middle East project, where it moved the five issues: water, economic solidarity, refugees, armament away from the framework of the Madrid Conference, according to the European Economic Committee, into the framework of economic summits.

6. An attempt to achieve the recognition of Israel as a state in the region through its full relations with Arab states and Arab businessmen as a target for the Middle East.

7. To prioritize economic projects for regional cooperation projects first and not for individual projects to enable Israel to greatly benefit from them.

\section{References}

\subsection{Arabic references:}

Agha, Hussein, et al. (1982). World Economic Issues. The Arab Institution for Studies and Publication. (1 st edition). Beirut. Peres, Shimon. Mohamed Helmy Abdel Hafez (translator). 1994. The New Middle East. Amman: Al Ahlia Publishing and Distribution, 1.

Kantor, Robert. Zaher, A. (translator) (1989). Contemporary International Politics. Amman: Jordan Book Center.

Harrison, John, et al. Mansour, Taha Abdullah (translator) (1987). International Economic Relations. Dar al-Marikh Publishing.

\subsection{Foreign Books:}

Therodore, Coulombis; Wolfe, James. (1982). Introduction to International Relations: Power and Justice. Prentice-Hall inc Engle Wood Cliffs, 2nd Edition.

Holsti, KJ. (1995). International Politics: A Frame Work for Analysis. Prentice Hall, inc 7th edition.

Nafeh's Political Encyclopedia, Vol.1, 1969.

Spero, E. Jonn. The Politics of International Relations, London George Allen.

\subsection{Periodicals:}

International Political Magazine. (July 1994). No. 117.

Journal of Arab Affairs. (1994). No. 80.

Journal of Arab Futurer (Al-Mustakbal Al-Arabi). (1990). No. 133.

Journal of International Politics. (January 1997). No. 127.

Journal of Arab Future (Al-Mustakbal Al-Arabi). (1995). No. 196.

Journal of Arab Future (Al-Mustakbal Al-Arabi). (February, 1990). No. 204.

Journal of International Politics. (October, 1996). No. 126.

\footnotetext{
${ }^{29}$ Journal of the Future Arab. No. 204. (February, 1996). p. 23.
} 